\title{
A positivist approach to rights of nature in the European Union
}

\author{
Yaffa Epstein* \\ Swedish Collegium for Advanced Study and Uppsala University Faculty of Law \\ Hendrik Schoukens** \\ Ghent University Department of European, Public \& International Law
}

A growing number of jurisdictions throughout the world have recognized some type of legal rights of nature. This jurisprudential trend has thus far made few inroads in Europe. However, its apparent absence is misleading. In this article we argue that, explicit or not, nature as protected by European Union (EU) law already has certain legal rights in the Hohfeldian sense because other entities have legal obligations towards it. Moreover, we argue that recent decisions of the Court of Justice of the $E U$ can be interpreted to support our claim that nature, as protected by EU law, already enjoys some legal rights that cannot be trumped by mere utilitarian interests, and that these rights can in turn be recognized and applied by national courts. We further suggest that public interest litigation can contribute to developing rights for nature in Europe, even absent any explicit recognition of these rights in EU law or in national legislation.

Keywords: rights of nature, public interest litigation, EU law, Hohfeld, strategic litigation, environmental law, natural entities

\section{INTRODUCTION}

When Christopher Stone wrote his now famous 1972 article 'Should Trees Have Standing?', ${ }^{1}$ his case for nature as a subject of rights was not widely embraced by the legal academic community. ${ }^{2}$ In the decades that followed, few scholars assessed the prospect of recognizing rights for natural entities as constituting a realistic pathway for environmental governance. Indeed, a powerful counterargument was that rights are a human invention and cannot be applied outside the realm of the human: 'There were no rights over the millennia of evolutionary time - nor are

* yaffa.epstein@jur.uu.se.

** hendrik.schoukens@ugent.be. Thank you for very helpful feedback to Eva Bernet Kempers, Thérèse Björkholm, Elin Boyer, Anna Grear, Emille Boulot, Joshua Sterlin, and two anonymous reviewers. Research funding from the Swedish research council Formas on project 2019-01450 is gratefully acknowledged.

1. Christopher Stone, 'Should Trees Have Standing? Towards Legal Rights for Natural Objects' (1972) 45 Southern California Law Review 450.

2. See notably, Peter Burdon, 'The Rights of Nature: Reconsidered' (2010) 49 Australian Humanities Review 69, 79. 
there today, outside the human sector' ${ }^{3}$ To use the language of rights outside the context of the human and moral community would therefore be ridiculous. ${ }^{4}$ However, in spite of such scholarly scepticism, the idea of recognizing rights of nature has in fact been implemented in a diverse and growing number of jurisdictions over the past 15 years, and especially over the last five years. ${ }^{5}$

By 'rights of nature' we mean legal rights for nature as a whole, or for natural entities such as particular rivers or ecosystems, or for categories of natural entities such as all of the rivers or ecosystems in a particular area. ${ }^{6}$ These diverse new rights have taken many forms and have been made part of the law in many different ways, often but not exclusively influenced by Indigenous legalities. Prominent examples include Ecuador's constitutional amendment recognizing rights for Nature or Pachamama ${ }^{7}$ Bolivia's national Law of the Rights of Mother Earth $;{ }^{8}$ New Zealand's Whanganui River Claims Settlement; ${ }^{9}$ and court decisions such as the Bangladesh Supreme Court's recognition of rights for rivers ${ }^{10}$ and the Colombian Constitutional Court's and Colombian Supreme Court's recognitions of rights for the Atrato River ${ }^{11}$ and Amazon ecosystem ${ }^{12}$ respectively.

The rights for nature movement has, however, made few inroads in Europe thus far, despite significant interest. ${ }^{13}$ A 2016 environmental code for the Loyalty Islands, a province of the French territory of New Caledonia, was the first law in a European territory allowing for the possibility. ${ }^{14}$ The Sami Parliament, an elected body and Swedish state agency that represents the Indigenous people of Sweden, endorsed the NGO promulgated 'Universal Declaration of the Rights of Mother Earth' in 2018. In 2019, the Swedish Green Party proposed a constitutional amendment guaranteeing nature's rights ${ }^{15}$ although it is unlikely to succeed. Assertions of rights of nature have also been made through litigation, such as in the Belgian climate case

3. Holmes Rolston, III, 'Rights and Responsibilities on the Home Planet' (1993) 18 Yale Journal of International Law 251, 256.

4. ibid.

5. Guillaume Chapron, Yaffa Epstein and José Vicente López-Bao, 'A Rights Revolution for Nature' (2019) 363 Science 1392.

6. For a comparison of different types of legally recognized natural entities, see Craig M Kauffman and Pamela L Martin, 'Constructing Rights of Nature Norms in the US, Ecuador, and New Zealand' (2018) 18 Global Environmental Politics 43, Table 1.

7. Ecuador Constitution 2008, title II arts 70-73; Louis J Kotzé and Paola Villavincencio Calzadilla, 'Somewhere between Rhetoric and Reality: Environmental Constitutionalism and the Rights of Nature in Ecuador' (2017) 6 Transnational Environmental Law 401.

8. Law 071 of the Rights of Mother Earth of 2010 (Ley 071 de Derechos de la Madre Tierra).

9. Te Awua Tupua (Whanganui River Claims Settlement) Act 2017.

10. Writ Petition № 13989, Upheld by the appellate division of the Supreme Court of Bangladesh 2020.

11. Acción de tutela interpuesta por el Centro de Estudios para la Justicia Social 'Tierra Digna', Expediente T-5.016.242, T-622 de 2016.

12. STC4360-2018, Radicación $\mathrm{n}^{\circ}$ 11001-22-03-000-2018-00319-01.

13. Laura Schimmöller, 'Paving the Way for Rights of Nature in Germany: Lessons Learnt from Legal Reform in New Zealand and Ecuador' (2020) 9 Transnational Environmental Law 569, 585-6.

14. Code de l'environnement de la province des îles Loyauté (2016), art 110-3.

15. Motion 2019/20:3306 av Rebecka Le Moine m.fl., available at <https://www.riksdagen. se/sv/dokument-lagar/dokument/motion/naturens-rattigheter_H7023306> accessed 27 April 2021. 
(Klimaatzaak), in which two lawyers intervened in the pending procedures in the name of 82 protected trees, a matter as yet unresolved at the time of this writing. ${ }^{16}$ At the EU level, there has been some discussion of the incorporation of rights of nature in the EU legal framework through a directive ${ }^{17}$ or charter for the rights of nature, ${ }^{18}$ but to date no legislative action appears to be forthcoming in this regard. The question remains whether such significant alterations of EU law are currently feasible.

Although rights of nature have thus far had little success in being explicitly recognized in law within the EU or within Europe more broadly, we argue that nature does have legal rights in the EU legal order by virtue of the legal obligations owed to it under existing environmental laws. EU environmental laws impose positive obligations to take measures to protect - and negative obligations to refrain from harming - various aspects of the environment, for example air, ${ }^{19}$ water, ${ }^{20}$ habitats, ${ }^{21}$ and species. ${ }^{22}$ And what does it mean to have a right, if not to be the beneficiary of a legal duty? Using a Hohfeldian conception of legal rights as correlatives of legal obligations, ${ }^{23}$ we argue that currently existing obligations to nature can be understood as legal rights of nature. These legal rights can accordingly provide a legal basis for Member State and EU courts to interpret and adjudicate, and thereby to further develop, rights of nature. Furthermore, we claim that these existing rights have at times been implicitly treated as rights by EU courts when they strictly interpret protective laws without regard to utilitarian or economic considerations. Finally, we argue, environmental NGOs fulfil the role of legal guardians of rights-bearing natural entities when they represent nature's rights in court to enforce EU environmental law.

The intersection between rights of nature and existing EU environmental law is, to a large extent, still uncharted territory in legal literature. ${ }^{24}$ Ludwig Krämer has largely dismissed the potential for rights of nature in the EU, arguing in a 2020 article that the main lesson for the EU from foreign rights recognitions for nature is that they

16. Klimaatzaak v Belgian Federal Gvt, Flemish Gvt and Walloon Gvt, case no. RG $\mathrm{N}^{\circ} 15-$ 4585-A; see: <https://www.hln.be/wetenschap-en-planeet/82-bomen-stappen-naar-de-rechterze-willen-rechten a62a5057/> accessed 27 April 2021.

17. Mumta Ito, 'Nature's Rights: Why the European Union Needs a Paradigm Shift in Law to Acheive its 2050 Vision' in Cameron La Follette and Chris Maser (eds), Sustainability and the Rights of Nature in Practice (CRC Press, Boca Raton 2019) 327.

18. Michele Carducci and others, Towards an EU Charter of the Fundamental Rights of Nature (European Economic and Social Committee 2019), available at <https://www.eesc.europa. eu/sites/default/files/files/qe-03-20-586-en-n.pdf> accessed 27 April 2021.

19. For example, Directive 2008/50/EC of the European Parliament and of the Council on ambient air quality and cleaner air for Europe [2008] OJ L 152.

20. For example, Directive 2000/60/EC of the European Parliament and of the Council establishing a framework for Community action in the field of water policy [2000] OJ L 327.

21. For example, Council Directive 92/43/EEC on the conservation of natural habitats and of wild fauna and flora [1992] OJ L 206.

22. ibid.

23. Wesley Newcomb Hohfeld, 'Some Fundamental Legal Conceptions as Applied in Judicial Reasoning' (1913) 23 Yale Law Journal 16; Wesley Newcomb Hohfeld, 'Fundamental Legal Conceptions as Applied in Judicial Reasoning' (1917) 26 Yale Law Journal 710.

24. Hendrik Schoukens 'Rights of Nature in the European Union: Contemplating the Operationalization of an Eco-Centric Concept in an Anthropocentric Environment?' in Joana Castro Pereira and André Saramago, Non-Human Nature in World Politics: Theory and Practice (Springer 2020) 205-34. 
highlight the importance of access to justice before national courts. ${ }^{25}$ Similarly, when analysing the potential added value of rights of nature for the EU, Julien Bétaille has argued that many existing environmental laws in the EU already reflect ecocentric perspectives from which rights talk would only distract. ${ }^{26}$

Like these scholars, we agree that current EU environmental law, if fully enforced, mandates strong environmental protection. In fact, we claim that this strong protection amounts - in effect - to an award of rights. Unlike these authors, however, we argue that rights have value for nature. To point out that legal obligations can be reframed as a grant of rights may seem facile, but language matters. As Stone argued, "judges who could unabashedly refer to the "legal rights of the environment" would be encouraged to develop a viable body of law - in part simply through the availability and force of the expression'. ${ }^{27}$

Our argument is built on a positivist view of rights - we seek to identify rights that can be said to exist already in the EU legal order. We concede however that the value of rights lies in part in their normative force. When people talk about obligations to natural entities as rights held by those entities, they implicitly acknowledge the intrinsic value of those entities, and when they talk about rights of natural entities in litigation, they give courts the opportunity to do the same. Such reasoning is to an extent circular, but the legal process is iterative: introducing rights into legal discourse has the potential to lead to improved protection for natural entities.

This article links a Hohfeldian analysis of rights with new ways to frame rights of nature within the EU legal order. The analysis will open with a discussion of Hohfeldian rights and clarify why nature already has these rights where the law establishes clear obligations for humans with respect to nature. The article will then turn its focus to the substantive rights that EU nature conservation law bestows upon nature, using the example of wild animals, in particular wolves. We will then discuss legal developments involving EU environmental rights for individuals and NGOs, focusing on the interplay with existing fundamental rights within the EU legal order and drawing on recent judicial decisions issued by the Court of Justice of the European Union (CJEU) regarding environmental rights. The article will lastly discuss the potential for litigation related to rights of nature in the EU.

\section{RIGHTS AS JURAL RELATIONS}

The nature of rights is one of the persistent questions of jurisprudence. Adding to conceptual difficulties is the fact that the term 'right/s' is used in many different ways in both legal and ordinary contexts. The term 'right' is used descriptively (of existing legal relationships) as well as normatively (communicating 'moral' content to make a normative case of some kind). The boundaries between these uses can be unclear.

25. Ludwig Krämer, 'Rights of Nature and their Implementation' (2020) 17 Journal for European Environmental \& Planning Law 47.

26. Julien Bétaille, 'Rights of Nature: Why it Might Not Save the Entire World' (2019) 16 Journal for European Environmental and Planning Law 35.

27. Stone (n 1) 22-3. This supposition has proved true in Ecuador, where constitutional rights for mother earth have resulted in a growing body of precedent developing expanding the application of Nature's rights. Craig M Kauffman and Pamela L Martin, 'Can Rights of Nature Make Development More Sustainable? Why Some Ecuadorian Lawsuits Succeed and Others Fail' (2017) 92 World Development 130, 139. 
Establishing that there is a legal right, for example, is often grounds for concluding that there should be such a right. Further, as argued by legal realist Felix Cohen, ${ }^{28}$ a court's conclusion about whether a legal right exists is often based on circular logic. For instance, in an example given by Cohen, a court held that there was a right to sue a labour union because the labour union was a legal person. It would be equally accurate (and as circular), Cohen explained, to say that the labour union was a legal person because the court held that there was a right to sue it. ${ }^{29}$

The concept of legal rights may be devoid of meaningful content, as legal realists have contended, but rights are nevertheless an enduring and essential part of Western legal systems. By pointing out where rights for non-humans can be found in existing law, we open the door for further conclusions both about what those rights entail and bring entitlement to, and even concerning the expansion of legal personhood. While rights concepts are frequently ambiguous and vague, and while this very ambiguity and vagueness to some extent contributes to the evolution of rights, starting with conceptual clarity is generally regarded as good jurisprudential practice. Wesley Newcomb Hohfeld's well-known articles from 1913 and 1917 on 'fundamental legal conceptions as applied in judicial reasoning' are seminal works providing conceptual clarity for a positivist analysis of rights. ${ }^{30}$

In these works, Hohfeld laid out his famous taxonomy for understanding what is meant when speaking of rights and duties, and for clarifying the various jural relationships described by these different concepts. Hohfeld's taxonomy has been analysed extensively by legal scholars, including in several recent works on rights for nonhumans, ${ }^{31}$ and therefore will be recounted only briefly here.

Hohfeld argued that what are referred to as rights and duties in law actually describe several different concepts and that what is meant by the term 'right' in any particular context can be understood in part by examining what sort of duty or other legal disablement is correlated with that right. ${ }^{32}$ Hohfeld's taxonomy includes four types of rights: (a) claim-rights (or rights 'in the strictest sense') $;^{33}$ (b) liberties; ${ }^{34}$ (c) powers; and (d) immunities. ${ }^{35}$ Each of these types of rights correlates to a type of disablement: (a) duties; (b) no-rights; (c) liabilities; and (d) disabilities, respectively. ${ }^{36}$ Each set of paired terms describes a legal relationship. If a person has a claim-right to something, another person has a duty to provide it. If a person has a liberty to do something, another person has no-right to stop them. If a person has a power to alter legal relations, someone else has the liability to have that legal relationship

28. Felix S Cohen, 'Transcendental Nonsense and the Functional Approach' (1935) 35 Columbia Law Review 809.

29. ibid 813-14.

30. Hohfeld (1913) (n 23) 29; Hohfeld (1917) (n 23).

31. Eg, Joshua C Gellers, Rights for Robots: Artificial Intelligence, Animal and Environmental Law (Routledge, Milton Park 2021); Visa AJ Kurki, A Theory of Legal Personhood (Oxford University Press, Oxford 2019); Torben Spaak, 'Animal Law: Human Duties or Animal Rights?' (2021) 67 Scandinavian Studies in Law 225; Saskia Stucki, 'Towards a Theory of Legal Animal Rights: Simple and Fundamental Rights' (2020) 40 Oxford Journal of Legal Studies 533 .

32. Hohfeld (1913) (n 23) 31.

33. ibid 30.

34. Hohfeld called these privileges, but following more recent authors, we refer to them as liberties.

35. Hohfeld (1913) (n 23) 30-59.

36. ibid. 
altered. And if a person has an immunity from having a particular legal relationship altered, another person has a disability from altering that relationship.

Hohfeld was not making a claim about the substantive content of rights. Each conception of a Hohfeldian entitlement is simply another way to express that in each case a correlative limitation also exists. ${ }^{37}$ In Hohfeldian terms, it is equally true to say, for example, that the state has a legal duty to provide children with an education because children have a legal right to an education as it is to say that children have the legal right to an education because the state has a legal duty to provide one. These are two ways of expressing the same legal relationship.

Existing environmental laws impose many duties to protect nature upon both public authorities and private individuals. The limitations placed by law on people can take a variety of Hohfeldian forms. For example, people might have a duty not to emit pollutants into a river. They might also have no-right to prevent it from changing its course; the liability that their land will become protected habitat if the river does change its course; and a disability from converting the water to their ownership or selling it. Such relationships between the authorities and individuals and protected nature, we argue, amount to Hohfeldian rights for the river: a claim-right not to be polluted; a liberty to change its course; the power to change the legal rights of land owners; an immunity from being owned or sold.

Hohfeldian rights describe legal relationships between two persons. ${ }^{38}$ We will argue that these relationships also exist between persons and legally protected nature (or a natural entity or system), whether or not nature (or a natural entity or system) is considered to be a legal person. This claim, of course, is not without its challengers.

Hohfeld himself, for example, would likely refute the suggestion: he argued that legal relationships can only exist between humans: '.. since the purpose of law is to regulate the conduct of human beings, all jural relations must, in order to be clear and direct in their meaning, be predicated of such human beings' ${ }^{39}$ Indeed, Hohfeld wrote that although certain rights and duties exist 'in rem', underlying 'in rem' claims against property are claims against human parties. Presumably, Hohfeld's intention was to avoid what might have been considered the absurd result that his taxonomy might be said to require legal duties or even rights for land or other objects. ${ }^{40}$ However, Hohfeld's insistence that 'A right in rem is not a right "against a thing", but rather a right against each of the persons who actually have the correlative obligation, ${ }^{41}$ and that a duty in rem is also not owed to a thing, but rather to each of the holders of the correlative rights, ${ }^{42}$ points to a solution that perhaps would satisfy him. Environmental laws often intend to protect not only people, but also nature or some aspect of nature. ${ }^{43}$ And, where nature is an intended beneficiary of nature

37. Pierre Schlag 'How to Do Things with Hohfeld' (2015) 78 Law and Contemporary Problems 185, 201.

38. ibid 200 .

39. Hohfeld (1917) (n 23) 721.

40. See Christopher M Newman, 'Hohfeld and the Theory of in Rem Rights: An Attempted Mediation' George Mason University Legal Studies Research Paper Series LS 17-07, 12, available at <https://ssrn.com/abstract=2925392> accessed 27 April 2021: 'He treats the phrase [in rem] as though it can only be taken literally, as though if it means anything, it must mean that Blackacre has duties to its owner for which it can be answerable at law'.

41. Hohfeld (1917) (n 23) 720.

42. ibid 745 .

43. Roderick Frazier Nash, The Rights of Nature: A History of Environmental Ethics (University of Wisconsin Press, Madison 1989) 85. 
protection law, arguably the duties created are actually owed to nature. We therefore suggest that correlative jural rights also belong to nature. Such an argument has been frequently made in the context of animal rights, ${ }^{44}$ and seems similarly applicable to rights for nature.

This argument that entities whose interests are legally protected for their own sakes can be rights holders accords with the interest theory of rights. Joseph Raz's wellknown formulation of the interest theory addresses both the definition of rights and who can be a rights holder:

Definition: ' $\mathrm{X}$ has a right' if and only if $\mathrm{X}$ can have rights, and, other things being equal, an aspect of X's well-being (his interest) is a sufficient reason for holding some other person(s) to be under a duty. [Citation omitted.]

Capacity for possessing rights: An individual is capable of having rights if and only if either his well-being is of ultimate value or he is an 'artificial person' (e.g. a corporation). ${ }^{45}$

As one of us, and others, have noted elsewhere, the interest theory of rights provides theoretical support for non-human rights when the non-human entity has been explicitly granted legal personhood, or if it is valued for its own sake rather than for its usefulness to others. ${ }^{46}$ Natural entities have of course not yet been granted legal personhood within the EU. However, it can be argued that under EU law some natural entities are valued for themselves rather than for their instrumental value, or at least for more than their instrumental value. In particular, the Convention on Biological Diversity, to which the EU is a party, and which informs EU biodiversity policy, recognizes the 'intrinsic value' of biological diversity, along with economic and other values. ${ }^{47}$ Whether nature or its components have ultimate and intrinsic value or only instrumental value is a philosophical question that this article does not attempt to address. Accordingly, this article is not concerned with what entities actually have intrinsic value. However, we will offer some arguments later about the intrinsic value of natural entities reflected in the EU legal order, and thus draw upon the interest theory of rights in support of this article's core proposition.

Another challenge to the claim that Hohfeldian rights can be meaningfully applied to the non-human is presented by the argument that rights discourse is not useful for non-humans, and therefore the focus should be on human obligations. This is the argument made, for example, by Torben Spaak in the context of addressing rights versus welfare approaches to animal protection. ${ }^{48}$ Although legal duties owed to animals could be viewed as Hohfeldian rights for animals, Spaak argues, such an approach would be pointless or incoherent. ${ }^{49}$ Spaak acknowledges that, analysed in conjunction with an interest theory of rights, animals may have Hohfeldian claim-rights and therefore are 'in a minimal sense legal subjects' ${ }^{50}$ But while he states that claim-rights might be 'interesting' for animals, he dismisses such rights as being nothing more than a reflex of the relevant duty, and therefore no more useful to animals than being the beneficiary of a duty. ${ }^{51}$ He concludes that claim-rights are therefore without

44. Eg, Stucki (n 31).

45. Joseph Raz, The Morality of Freedom (Clarendon Press, Oxford 1986) 166.

46. For example, Stucki (n 31) 540-43; Chapron, Epstein and López-Bao (n 5) 1392.

47. The Convention on Biological Diversity of 5 June 1992 (1760 U.N.T.S. 69).

48. Spaak (n 31).

49. ibid 252-3.

50. ibid 249.

51. ibid. 
value for animals. He further dismisses other Hohfeldian rights as being even less useful for animals. For example, he contends that, while it is inarguably true that animals have the Hohfeldian liberty to roam free in the sense that animals have no legal duty not to roam free, this liberty-right would be 'pointless for animals' and therefore 'misleading, albeit true in a loose and vacuous sense'. ${ }^{52}$ Spaak would presumably extend these arguments to rights for nature.

The essence of Spaak's appraisal is that while Hohfeld's taxonomy accurately describes some relationships between human and non-human, it is nevertheless not useful to frame these relationships as rights. We disagree. Establishing, for example, that an ecosystem has a right to exist is only pointless if legal rights are pointless. Additionally, it is difficult to see why rights are any more pointless for animals (or nature) than they are for people. ${ }^{53}$ After all, people's rights have also been criticized as being vacuous or illusory or a tool of capitalism. ${ }^{54}$ Even if this claim is, in some respects, true, and even if there are deficiencies in the legal protections afforded by rights, the concept(s) of rights continue to play an essential role in all Westerninfluenced legal systems. Accordingly, and in line with Stone's argument introduced above, if it is true that establishing that legal rights for nature already exist enables these rights to be interpreted and developed, it is meaningful to identify all the types of rights that exist in the legal system. Such rights-making discourse has potentially valuable impacts.

Asserting the value of rights, Saskia Stucki has argued that rights for animals are important because they can allow animals' interests to be given real consideration when weighed against humans' rights, because rights have normative force and because infringement of rights requires justification beyond a mere reason. ${ }^{55}$ Stucki distinguishes between what she calls 'simple animal rights', which are the Hohfeldian rights that correlate with legal duties towards animals that exist in law, and 'fundamental animal rights', which are comparable to human rights, and which are, she argues, necessary for the robust legal protection of animals. ${ }^{56}$ The Hohfeldian rights contained in current animal welfare laws, she argues, are 'imperfect' and 'weak' because they protect only secondary interests (for instance the interest in being killed in a painless manner rather than the interest in not being killed at all) and because they are easily infringeable. ${ }^{57}$ While we largely agree with Stucki's analysis, we nevertheless argue that for protected nature, currently existing Hohfeldian rights are rather strong. These rights correlate to strictly interpreted duties on the part of others that may not be infringed for mere economic reasons and can be called on in court to demand cessation or remediation of damaging activities. Further, and as also argued by Stucki in the context of animal rights, Hohfeldian 'simple' rights could also provide a legal position from which to argue for the development of fundamental rights. ${ }^{58}$

52. ibid.

53. Indeed, Spaak, a proponent of the will theory of rights, also rejects the idea that children or incapacitated persons have rights, ibid 244.

54. For example, Radha D'Souza, What's Wrong with Rights? Social Movements, Law and Liberal Imaginations (Pluto Press, London 2018); Duncan Kennedy, 'The Critique of Rights in Critical Legal Studies' in Wendy Brown and Janet Halley (eds), Left Legalism/Left Critique (Duke University Press, Durham 2002).

55. Stucki (n 31) 554-5.

56. ibid.

57. ibid 549 .

58. ibid 552. 
The positivist Hohfeldian argument might be seen by those arguing for the moral rights of non-humans as being insufficient because rights recognitions for nature are said to add value beyond ordinary protection laws precisely because moral rights cannot be removed at the whim of the legislator, ${ }^{59}$ while legal rights as correlatives to legal obligations only exist to the extent to which the obligation exists in law. Indeed, several authors have, for this and other reasons, criticized positivist approaches to rights for nature as insufficient. For example, Miguel Vatter rejects the idea that positivist rights for nature could be meaningful as these rights would always be subordinated to the fundamental individual rights that form the basis of Western legal systems. ${ }^{60}$ Joshua Jowitt, arguing that animals must have moral rights, claims that positivist views of law are necessarily unable to protect animal interests because positivists view the recognition of rights for non-humans (and humans?) as being non-essential to a legal system. ${ }^{61}$ What good, these authors seem to ask, are non-human rights in a liberal, anthropocentric legal system that considers the non-human to be mere property?

Our response to these objections is that legal rights are a good starting place. We espouse a positivist view of legal rights for nature: nature has legal rights because it is owed legal duties. Our positivist argument suggests, in other words, that non-humans already have rights where their interests are protected by law and that these legal rights allow the interests of non-humans to be considered in the legal context and to be weighed against the rights of humans and others. Such legal rights are not, moreover, incompatible with moral rights arguments, and by establishing that nature has rights that can be invoked even in our current anthropocentric legal system, further rights developments - including in fundamental rights conceptions - become more accessible and imaginable.

\section{SUBSTANTIVE RIGHTS FOR NATURE: THE WOLF AS EXAMPLE OF A HOHFELDIAN RIGHTS HOLDER}

In this section we examine what rights nature currently has in EU law, using the example of the legally protected grey wolf (Canis lupis). Species protection straddles the conceptual border between animal rights (animal welfare protection) and rights of nature (nature protection). Accordingly, wolves - could be argued to have rights as individual animals or as collective natural entities. Both things seem to be reflected in EU nature protection law.

The starting point of our analysis is article 12(1) of the EU Habitats Directive, which imposes an obligation on Member States to establish a system to strictly protect wolves and other listed species. ${ }^{62}$ This system of protection must include prohibitions of:

(a) all forms of deliberate capture or killing of specimens of these species in the wild;

(b) deliberate disturbance of these species, particularly during the period of breeding, rearing, hibernation and migration;

59. Chapron, Epstein and López-Bao (n 5).

60. Miguel Vatter, 'Nature's Law or Law's Law? Community of Life, Legal Personhood, and Trusts' in Marc de Leeuw and Sonja Van Wichelen (eds), Personhood in the Age of Biolegality (Springer, New York 2019).

61. Joshua Jowitt, 'Legal Rights for Animals: Aspiration or Logical Necessity?' (2020) 11 JHRE 189.

62. Habitats Directive art 12(1). 
(c) deliberate destruction or taking of eggs from the wild;

(d) deterioration or destruction of breeding sites or resting places. ${ }^{63}$

Additionally, Member States must 'prohibit the keeping, transport and sale or exchange, and offering for sale or exchange, of specimens taken from the wild' ${ }^{64}$ Member States implement these laws in a variety of ways, for example by enacting limitations on hunting and activities that would damage wolves' dens. ${ }^{65}$ As already underscored above, these restraints and obligations on human activity can be reframed as Hohfeldian rights for protected species. Some of these rights seem to be collective rights for wolf populations, and some - particularly those arising in correlation to the protection of 'specimens' of the species - seem to be individual rights, applying to each wolf.

Because there is a legal obligation to refrain from capturing or killing individual wolves, wolves have the claim-right not to be captured or killed. One might also argue by analogy for fundamental rights for wolves, drawing comparisons to fundamental human rights to life or liberty. For instance, the Charter of Fundamental Rights of the European Union (the Charter) states unconditionally that 'Everyone has the right to life', ${ }^{66}$ while, according to the European Convention on Human Rights, no one 'shall be deprived of his life intentionally save in the execution of a sentence of a court following his conviction of a crime for which this penalty is provided by law' ${ }^{67}$ Irrespective of whether or how wolves' rights not to be captured or killed could be related to conceptions of fundamental rights, wolves have these legal rights in the positive law of the European Union that correspond to the existence of a legal duty not to capture or kill them.

Similarly, because there is a positive legal obligation not to deliberately disturb the wolf species, wolves have the claim-right not to be disturbed - and perhaps by analogy to the quiet enjoyment of their habitat, or at least of the core areas of their habitat. This right might be compared to the Charter's right to respect for private and family life, ${ }^{68}$ the right to marry and found a family, ${ }^{69}$ and the solidarity right to family life. ${ }^{70}$ One might even equate the protection of a wolf den and its immediate surroundings to a property right, albeit a temporary one. Again, whether or not such fundamental rights and/or their analogies might eventually develop, the existing legal obligation correlates to a legal right that is defensible in court. And because deterioration or destruction of breeding sites or resting places is prohibited, wolves have the claim-right that their breeding sites or resting places not be disturbed or destroyed, a position perhaps comparable to the fundamental right to property and to protection from expulsion. ${ }^{71}$ Since the keeping, transport and sale or exchange of wolves is also prohibited, wolves have the claim-rights not to be held or transported, and a Hohfeldian immunity from

63. ibid.

64. Habitats Directive art 12(2).

65. Hendrik Schoukens and Kees Bastmeijer, 'Species Protection in the European Union: How Strict Is Strict?' in Charles-Hubert Born and others (eds), The EU Habitats Directive in its EU Environmental Law Context: European Nature's Best Hope (Routledge, Milton Park 2005) 121 , at $128-9$.

66. Charter of Fundamental Rights of the European Union [2012] OJ C326/391 ('Charter') art 2.

67. European Convention on Human Rights art 2.

68. Charter art 7.

69. Charter art 9.

70. Charter art 33.

71. Charter arts 17, 19. 
being made property. This right may be compared with the human right not be enslaved, which is enshrined in the prohibitions on slavery and forced labour in the Charter $^{72}$ and in the European Convention. ${ }^{73}$

The Habitats Directive allows for exceptions to be made from the duties not to harm species in certain well-delineated circumstances, which allows room for human interests to be weighed against nature's rights. Some authors point to the derogation clauses as proof of the anthropocentric nature of the EU Habitats Directive, ${ }^{74}$ but the fact that the prohibitions can be derogated from under restrictive conditions does not make the right not to be killed, for example, any less of a legal right. This lack of absoluteness is not an inherent obstacle to comparisons to fundamental rights, moreover. After all, most human rights are also non-absolute, and even those that are, such as the right to life, are subject to certain exceptions. People have the right to life, but it is nevertheless legal to kill someone in self-defence, or for authorities to put a person in harm's way when there is a strong enough countervailing interest. ${ }^{75}$ While the countervailing interests do not need to be nearly as strong to kill a wolf as to kill a human being under EU law, both situations require balancing. Wolf rights may be more akin to 'qualified' human rights, which can be restricted in some circumstances and within certain limits. These rights, such as the right to freedom of expression or the right to privacy and respect for family life, are written in a qualified manner: after the right to be protected is outlined, the remainder of the provision establishes whether (and the conditions under which) a public authority can legitimately restrict the right in order to protect the wider public interest. As with human rights, then, the fact that wolves' rights are not absolute does not mean that they are not meaningful rights. Under the Habitats Directive, derogations ${ }^{76}$ are strictly limited to situations where such derogation would not be harmful to populations of the species and where it is necessary to protect other species or habitats, to prevent serious damage to property, to protect public health and safety or other 'imperative reasons of overriding public interest', for research, education, or reintroducing the species or other rare and strictly defined circumstances. ${ }^{77}$ While economic concerns can be a factor in justifying derogation, they are never sufficient: it must also be true that derogation is not harmful to the affected population and that there are no other satisfactory alternatives. In other words, species' rights must sometimes be weighed against the rights or interests of other entities. If anything, this pattern of derogations and the reasons justifying them strengthen any analogy to human rights law, rather than weakening it.

These limitations on species' rights can also, of course, be framed as Hohfeldian duties placed upon the species. The potential for animals to have duties has been dismissed by most animal rights scholars: Spaak for instance writes that it is 'obvious'

\section{Charter art 5.}

73. European Convention art 4.

74. See for example Katarina Hovden, 'The Best is Not Good Enough: Ecological (Il)literacy and the Rights of Nature in the European Union' (2018) 15 Journal for European Environmental \& Planning Law 281, 299.

75. For example, see European Convention on Human Rights article 2, paragraph 2: 'Deprivation of life shall not be regarded as inflicted in contravention of this Article when it results from the use of force which is no more than absolutely necessary: (a) in defence of any person from unlawful violence; (b) in order to effect a lawful arrest or to prevent the escape of a person lawfully detained; (c) in action lawfully taken for the purpose of quelling a riot or insurrection.' 76. Habitats Directive art 16.

77. Habitats Directive art 16(1). 
that animals cannot have legal duties. ${ }^{78}$ Stucki writes that 'animals are in a constant state of "no duty" and thus "liberty". ${ }^{79}$ In Hohfeldian terms however, wolves could be said to have a duty not to harm excessively other species or habitats, a duty not to cause serious damage to property, a duty not to harm the public interest, and perhaps a no-right not to be subject to research. And while it might seem impossible for natural entities to have duties (as it is often assumed that having a legal duty requires the capacity to understand the law or at least to act with intention), ${ }^{80}$ several of the jurisdictions that have already explicitly recognized rights for nature have in fact also recognized nature's duties: for example New Zealand's Whanganui river was declared have 'all the rights, powers, duties, and liabilities of a legal person' ${ }^{81}$ These laws suggest that the only limitation upon the construction of a legal duty placed upon a nonhuman natural entity or system would be a limitation of legal imagination.

While the Hohfeldian rights which currently exist for species have not been called 'rights' by courts, we argue that that the CJEU has treated the protection of wolves as being akin to rights when weighing the protection of wolves against human rights and interests. Once a species is strictly protected, human duties owed to the species will not be abridged for mere economic convenience or for other reasons without a stringent examination of the necessity of the proposed harm and the potential impact on the wolf population. Increasingly, wolves' re-emergence in urban areas is giving rise to lawsuits centring on the weighing of wolf protection against protections for humans' interests contained in the relevant derogation provisions, such as on the basis of public safety and the protection of livestock. The CJEU has consistently given a strict interpretation to EU nature protection law, making it very hard legally to harm protected species and habitats even when humans have an interest in doing so.

The obligation not to capture wolves was considered in relation to the interest in public safety by the CJEU in the 2020 Romanian wolf case. ${ }^{82}$ In that case, a wolf that had been straying into a Romanian village was captured and relocated by local authorities. The CJEU noted in its decision that the protection duties provided for by article 12(1) of the EU Habitats Directive were not limited to wilderness areas: ${ }^{83}$ the wolf was protected wherever the wolf was present during the course of its natural behaviour. ${ }^{84}$ Although species are protected 'in the wild' according to article 12(1) of the Habitats Directive, this does not mean that wolves are not protected when they enter human settlements, only that the law does not apply to specimens that were legally held in captivity. The result is that, in practical terms, wolves have not just a liberty but also a claim-right to roam through human settlements, in that humans have a duty not to relocate them. Even when there is an acknowledged potential conflict with public safety, a determination that the threat in fact existed, and that relocation was necessary and would not be unduly harmful to the wolf population is required to justify limiting the duty to allow wolves to be present in their natural range.

It is particularly interesting that the EU judges explicitly referred to the reasons why wolves more frequently appear in human settlements. The CJEU noted that the development of infrastructure, illegal logging, farming and certain industrial

78. Spaak (n 31) 248-9.

79. Stucki (n 31) 538.

80. Kurki (n 31) 78.

81. Te Awa Tupua (Whanganui River Claims Settlement) Act 2017 art 14.

82. Case C-88/19 Alianţa pentru combaterea abuzurilor (2020) ECLI:EU:C:2020:458.

83. ibid paras 38-9.

84. ibid. 
activities push wolves further towards areas occupied by humans. ${ }^{85}$ Likewise, the CJEU referred to species-specific characteristics of wolves, such as the fact that wolves use relatively large habitats, as being a justification for why it would be unreasonable to limit the protection of wolves to sites that have been explicitly designated as protected sites. ${ }^{86}$ In other words, the court relied on the ecological requirements of the wolves to guide its decision. This focus on the wolf's needs supports our broader claim that the EU legal system currently treats natural entities as being the intended beneficiaries of nature protection laws, and the effect is that their legally protected interests are treated as rights when weighing their protection against countervailing human concerns.

Two rulings in which the CJEU had to assess the legality of Finnish wolf hunting practices seem to reinforce our argument that wolves' Hohfeldian rights are not easily infringed. ${ }^{87}$ While neither of the two cases explicitly touched upon the notion of rights of strictly protected species, the court in both cases used quite a strict standard for derogation from wolf protection when weighing the duty not to kill wolves against humans' property rights and other interests.

The first of these decisions came in 2007, and concerned the killing of wolves to prevent 'serious damage to livestock', which is one of the grounds for derogation. ${ }^{88}$ While the CJEU did not rule out killing wolves for this purpose, it condemned Finland for non-compliance with article 16(1)(b) of the Habitats Directive because the shooting permits were not specific to the individual wolves that were likely to cause damage to livestock. ${ }^{89} \mathrm{Or}$, differently stated, no indiscriminate wolf killings are permissible: while Member States do not have to prove that particular wolves have caused damage in order to kill them, the Member State does have to demonstrate a connection between the harm to be caused to the wolf and the prevention of serious damage, as well as that there was no satisfactory alternative to harming the wolf, and that the affected wolf population will not be harmed. ${ }^{90}$ In effect, the court required the Member State to carry out derogations using the most targeted means possible. Interestingly, Finland tried to justify its failure to target specific individuals by pointing out that the wolf is an animal that generally lives in a pack, and that as a result, hunting permits cannot always target the individual(s) that cause serious damage. ${ }^{91}$ However, this argument was dismissed by the CJEU on the ground that Finland had not submitted ecological scientific evidence to support this thesis. ${ }^{92}$

The more recent Tapiola case also implicitly concerned Finnish wolves' legal rights not to be killed under the Habitats Directive. ${ }^{93}$ In this case, Finland had authorized hunting based on the claim that allowing an annual hunting season to eliminate a set number of wolves would bolster support for an increased presence of wolves in the

85. ibid para 50 .

86. ibid para 37 .

87. Case C-342/05 Commission v Finland (2007) ECLI:EU:C:2007:341; Case C-674/17 Luonnonsuojeluyhdistys Tapiola Pohjois-Savo - Kainuu ry (Tapiola) (2019) ECLI:EU: C:2019:851, paras 39-41.

88. Case C-342/05 Commission v Finland (2007).

89. ibid paras 39-41.

90. ibid paras $31,47$.

91. ibid paras $41-2$.

92. ibid.

93. Case C-674/17 Tapiola (2019). 
Finnish countryside. ${ }^{94}$ More precisely, the case concerned whether wolves could be killed for the stated purpose of preventing their poaching. An NGO argued, and the Court held, that this hunting violated the Habitats Directive when it had not been proven that the hunting would have the stated impact. Whereas the CJEU accepted the permissibility - at least in theory - of tolerance hunting within the framework of the EU Habitats Directive, ${ }^{95}$ it held that rigorous scientific data needed to be provided to demonstrate that management hunting was the only available option to reduce illegal hunting, and that such hunting would have a net positive effect on the conservation status of the wolf population. ${ }^{96}$ In other words, the win for the anthropocentric perspective - in essence the CJEU accepted that derogation could be granted to strengthen human inhabitants' benevolence towards wolves - was conditional. As in its 2007 decision, the CJEU again seemed willing to take into account the ecological behaviour of wolves, ruling out indiscriminate killings of wolves in order to enhance the acceptance of these predators amongst humans. ${ }^{97}$ Whereas the Finnish hunting decisions included some guidance as to the types of individuals to be targeted, insufficient guarantees had been offered to preclude the killing of non-targeted specimens, and in fact a large percentage of non-targeted wolves had been killed. ${ }^{98}$ For a second time, the CJEU seemed to require a stringent assessment of hunting permits, in this situation targeting young individual wolves that could be linked to particular damage. If wolves had no intrinsic value, such a laborious and restrictive test would appear superfluous when authorizing derogations.

In the Tapiola case, the NGO argued that Finland had violated the Habitats Directive in allowing hunting for the purpose of preventing illegal killing without showing that doing so would lead to a net positive result for wolves. In its decision, the CJEU reaffirmed its stringent interpretation of the Habitats Directive's prohibitions on harming strictly protected species such as wolves. If the NGO had argued instead that wolves have the right under EU law not to be hunted for the purpose of preventing poaching when it had not been shown that doing so would lead to a net positive result for wolves, the substantive result would likely have been the same. The court might or might not have used the word 'right' in agreeing with the NGO's rights-based argument. Either way, invoking the claim of wolves' rights in the legal conversation provides a potential means to move the discourse forward, perhaps eventually towards wolves' fundamental right to life or to habitat.

\section{EVOLVING EU ENVIRONMENTAL RIGHTS: FOR WHOM?}

If, as we have argued, nature can be deemed to possess certain rights already under EU wildlife and environmental protection laws, it must nevertheless be admitted that these rights have been under-utilized by EU courts thus far. In this section, we discuss the possibility for EU courts to develop nature's rights.

94. Yaffa Epstein and Guillaume Chapron, 'The Hunting of Strictly Protected Species: The Tapiola Case and the Limits of Derogation under Article 16 of the Habitats Directive' (2018) 27 European Energy and Environmental Law Review 78.

95. Case C-674/17 Tapiola (2019), paras 39-41.

96. ibid paras 45,50 .

97. ibid paras $78-80$.

98. ibid paras 78-9. 
While the EU courts have not, of course, explicitly recognized rights for nature, they have already contributed to the evolution of environmental rights for humans and for NGOs. To illustrate the interplay between the EU treaties, Charter, secondary legislation, and judicial decision making in developing such environmental rights, we discuss some of these developments here. First, we examine substantive environmental rights: while EU law does not explicitly state that it creates environmental rights, clearly some substantive environmental rights for humans do arise from the environmental obligations in EU law; such rights for humans have been explicitly recognized in decisions of the CJEU and are interpreted and developed to varying degrees each time they are invoked in a legal process. Second, we examine the procedural environmental rights that have evolved to allow environmental NGOs to litigate in order to enforce EU environmental law. Finally, we posit that these procedural rights for environmental NGOs can imply substantive legal rights for nature: in enforcing laws intended to protect nature, we argue, NGOs fulfil the role of guardians for protected nature in all but name.

The EU treaties establish that the EU will work for a high level of both protection and improvement of the environment. ${ }^{99}$ The Treaty on the Functioning of the European Union (TFEU) further sets out how laws and policies within the EU will pursue this high level of protection. ${ }^{100}$ Article 191 of the TFEU elaborates several principles for environmental protection - such as the precautionary principle - but does not use any rights language concerning the environment. It is well established however, that EU courts develop rights based on general principles of EU law. Since the seminal 1969 Stauder case, in which the CJEU referred to the 'fundamental human rights enshrined in the general principles' of EU law, ${ }^{101}$ courts have continued to base judicial decisions on fundamental rights, and the treaties have subsequently been revised to reflect the rights thus recognized by EU courts. ${ }^{102}$ The precautionary principle has also been recognized by the EU courts as a general principle of EU law that requires authorities to give precedence to environmental protection, along with public health and safety, over economic interests, ${ }^{103}$ though leading scholar of EU environmental law Eloise Scotford has argued that this was not intended in the same sense as the general principles referenced in Stauder. ${ }^{104}$ More recently, the EU Charter of Fundamental Rights, which gained legal force along with the Treaty of Lisbon in 2009, has been applied in environmental cases. This Charter, which has the same legal status as the EU treaties, ${ }^{105}$ is said not to create new rights, but rather to recognize the 'rights, principles and freedoms' that were already part of the EU legal order. ${ }^{106}$ The Charter draws some distinction between rights and principles: rights are interpreted by courts,

99. TEU art 3.3.

100. TFEU art 114; TFEU title XX.

101. Case C-29/69 Stauder (1969) ECLI:EU:C:1969:57.

102. George Arestis, 'Fundamental Rights in the EU: Three Years After Lisbon, the Luxembourg Perspective' College of Europe Research Papers in Law, 2/2013<https://www.coleurope.eu/ research-paper/fundamental-rights-eu-three-years-after-lisbon-luxembourg-perspective $>$ accessed 27 April 2021.

103. Case T-74/00 Artegodan v Commission (2002) ECLI:EU:T:2002:283, para 184.

104. Eloise Scotford, Environmental Principles and the Evolution of Environmental Law (Hart Publishing, Oxford 2017) 184.

105. It is thus part of the primary EU level, which prevails over secondary EU legislation as well as any treaty or international agreements.

106. Charter preamble. 
while principles must be implemented in law before the courts can interpret them. ${ }^{107}$ This distinction, however, has been questioned. ${ }^{108}$ Importantly, as argued by former EU judge George Arestis, the Treaty of Lisbon allows the courts of justice to integrate new rights which are not written in the Charter but which would correspond to changes in society and would be established in the Member States'. ${ }^{109}$ Accordingly, it is clear that the EU courts play a continuing role in interpreting and developing the rights and principles set out in the Charter, and other rights that might not yet have been explicitly recognized or overtly enshrined in law.

The Charter contains provisions relevant to both substantive and procedural environmental protection. Article 37 deals with substantive environmental issues and reads: 'A high level of environmental protection and the improvement of the quality of the environment must be integrated into the policies of the Union and ensured in accordance with the principle of sustainable development'. Article 37 does not clarify whether environmental protection is a right or principle, but an explanatory document states that the 'principles' in this provision are based on the Treaty on European Union article 3(3) and TFEU articles 11 and $191 .{ }^{110}$ Additionally, the article 'also draws on the provisions of some national constitutions'. ${ }^{111}$

Most Member State constitutions contain reference to the environment. Some recognize a human right to a healthy environment, while others focus on duties towards the environment. It is not clarified in article 37 which constitutional provisions are drawn on, but nevertheless, while not identified as a right, 'environmental protection' is included as a provision of this legally binding document concerning fundamental rights in the European Union in its title on solidarity. ${ }^{112}$ Scotford has described this provision as 'ambiguous' and 'perplexing', but also as having 'the potential for innovative reasoning in shaping EU doctrinal developments'. ${ }^{113}$ The article has been interpreted in a small number of cases in the EU courts.

In the Associazione Italia Nostra Onlus case, for example, the Court, referring to the explanatory document, downplayed the significance of article 37, holding that it does not go beyond the environmental principles set out in the EU treaties. ${ }^{114}$ However, other CJEU decisions, such as the Grand Chamber decision in A and others, cite article 37 to support a demanding interpretation of environmental protection. ${ }^{115}$

As noted by Advocate General Kokott in Wasserleitungsverband Nördliches Burgenland, the high level of environmental protection in TFEU article 191, a basis for article 37 , is based on the precautionary principle and on the preventive principle. ${ }^{116}$ Other environmental principles named in article 191 of the TFEU are the principle

107. Charter art 52.

108. Chris Hilson, 'Rights and Principles in EU Law: A Distinction Without Foundation?' (2008) 15 Maastricht Journal of European and Comparative Law 193.

109. Arestis (n 102) 5.

110. Explanations relating to the Charter of Fundamental Rights, OJ C 303, 14.12.2007, pp. 17-35, Document 32007X1214(01).

111. ibid.

112. Charter art 37. Arts 27-38 are included in Title IV, Solidarity.

113. Eloise Scotford, 'Environmental Rights and Principles: Investigating Article 37 of the EU Charter of Fundamental Rights' in Sanja Bogojevic and Rosemary Rayfuse (eds), Environmental Rights in Europe and Beyond (Hart, Oxford 2018) 153.

114. Case C-444/15 Associazione Italia Nostra Onlus (2016) ECLI:EU:C:2016:978, paras 61-3. 115. Case C-24/19 A and others (2020) ECLI:EU:C:2020:503, para 44.

116. Opinion Advocate General Kokott Case C-197/18 (2019) Wasserleitungsverband Nördliches Burgenland (2019) ECLI:EU:C:2019:274. 
that environmental damage should be rectified at its source and that polluters should pay. Does enshrining the high level of environmental protection drawn from article 191 of the TFEU in the EU Charter mean that these environmental principles can be recognized as rights in the way in which EU principles were recognized as fundamental rights in Stauder? While the full implications of TFEU article 191 in respect of this question are currently unclear, the provision must have some legal effect, from which, potentially, a rights-based argument could be drawn.

Thus far, the rights holders recognized by the court in connection with environmental protection and with the fundamental rights enshrined in the Charter have been humans and human collectives - environmental NGOs. Even when EU secondary legislation does not contain explicit provisions regarding access to justice, as is the case with the EU Habitats Directive, national courts are required to ensure effective judicial protection in the field of biodiversity protection. ${ }^{117}$ The requirement for NGO access to bring litigation to enforce EU environmental law surfaced first in Lesoochranárske zoskupenie VLK I, better known as the Slovak Brown Bear case, where the CJEU held that the Aarhus Convention, while admittedly drafted in broad terms, could be used as an interpretative lens compelling domestic courts to ensure effective legal protection for environmental NGOs in cases where the EU Habitats Directive's protection schemes are infringed upon. ${ }^{118}$ The facts of the case are particularly interesting from the perspective of rights of nature. The lawsuit revolved around a Slovakian environmental NGO that challenged the legality of several hunting decisions concerning the brown bear, a strictly protected species under article 12(1) of the EU Habitats Directive. In other words, the case related to substantive protection duties set out by EU environmental law. However, pursuant to Slovakian law, environmental NGOs were denied standing in such cases. When assessing the limited standing options under national (Slovakian) law, the CJEU explicitly held that

In the absence of EU rules governing the matter, it is for the domestic legal system of each Member State to lay down the detailed procedural rules governing actions for safeguarding rights which individuals derive from EU law, in this case the Habitats Directive, since the Member States are responsible for ensuring that those rights are effectively protected in each case. ${ }^{119}$

Whereas the CJEU did not explicitly recognize the substantive rights of EU protected species, such as the brown bear, it seems to recognize that individuals and environmental NGOs can derive 'rights' from EU biodiversity legislation. It remains debatable whether the CJEU was aware of the full consequences of the wording it used in the aforementioned paragraph of its judgment. Of course, one might object that this case-law does not allow nature to directly claim standing before national courts: as Advocate General Sharpston is reported to have said at the hearing in Trianel before the CJEU, ${ }^{120}$ 'the fish cannot go to court'. ${ }^{121}$ Even so, this case in effect paves the

117. Hendrik Schoukens, 'Towards a Legally Enforceable Duty to Restore Endangered Species under EU Nature Conservation Law. On Wild Hamsters, the Rule of Law and Species Extinction' in J Jendroska and M Bar (eds), Procedural Environmental Rights: Principle X in Theory and Practice (Intersentia, 2018) 307.

118. Case C-240/09 Lesoochranárske zoskupenie VLK I (2011) ECLI:EU:C:2011:125, paras 46-7.

119. ibid para 47 (emphasis added).

120. Case C-115/09 Trianel (2011) ECLI:EU:C:2011:289.

121. Janez Potočnik, "The Fish Cannot Go to Court" - the Environment is a Public Good that Must Be Supported by a Public Voice', SPEECH/12/856 (23 November 2012). 
way for a guardianship approach, whereby environmental NGOs at the national level are authorized to step in and initiate lawsuits before domestic courts whenever the rights derived from the EU Habitats Directive are being violated.

This thesis finds even more support in recent jurisprudence, when the CJEU linked procedural environmental rights to the fundamental rights enshrined in the EU Charter of Fundamental Rights itself. Most noteworthy in this more general trend to ground procedural environmental rights in fundamental rights, is article 47 of the Charter, which guarantees a right to an effective remedy to 'everyone whose rights and freedoms guaranteed by the law of the Union are violated'. Decisions in several cases invoking this article develop the right to bring litigation to enforce the environmental law of the EU. For instance, in Lesoochranárske zoskupenie VLK II, the CJEU established that article 47, combined with the Aarhus Convention and substantive EU environmental law, gave rise to a right for environmental NGOs to seek enforcement of the substantive law in question. ${ }^{122}$ The CJEU continued to develop such rights for NGOs in the Protect Case. In that case, the court discussed the 'right to bring judicial proceedings ... read in conjunction with article 47 of the Charter, for the protection of the rights conferred by' article 4 of the Water Framework Directive. ${ }^{123}$ The CJEU held that

The right to bring proceedings ... would be deprived of all useful effect, and even of its very substance, if it had to be conceded that, by imposing those conditions, certain categories of 'members of the public', a fortiori 'the public concerned', such as environmental organisations ... were to be denied of any right to bring proceedings. ${ }^{124}$

The CJEU again discussed EU environmental law as giving rise to environmental rights in Wasserleitungsverband Nördliches Burgenland, holding that article 47, together with the Aarhus Convention and other EU environmental laws, imposes on Member States an obligation to ensure effective judicial protection of the rights conferred by EU law, in particular the provisions of environmental law. ${ }^{125}$ Here, the court discussed the provisions of EU environmental law as creating rights for individuals and environmental NGOs. Through the ability of individuals and environmental NGOs to bring litigation, environmental rights will continue to evolve in the EU.

While not explicit, substantive rights for nature are logically implied by the existence of environmental NGOs' article 47 and other procedural rights. A right to an effective remedy under article 47 only exists if someone's 'rights and freedoms guaranteed by the law of the Union are violated'. ${ }^{126}$ It has been established in the cases cited in the previous paragraphs that environmental NGOs have a fundamental right to an effective remedy when their procedural EU environmental rights are violated. However, these procedural rights would seem to imply an underlying substantive environmental goal that is being pursued. If an NGO seeks, for example, to halt the construction of a road through the habitat of an endangered species, does it seek to protect its own interests or the interests of the affected species?

122. Case C-243/15 Lesoochranárske zoskupenie VLK II [2016] ECLI:EU:C:2016:838, para 55 .

123. Case C-664/15 Protect Natur-, Arten- und Landschaftsschutz Umweltorganisation (2017) ECLI:EU:C:2017:987, para 52.

124. ibid para 46.

125. Case C-197/18 Wasserleitungsverband Nördliches Burgenland (2019) ECLI:EU: C:2019:824, paras 33-4.

126. EU Charter art 47, para 1. 
One possible answer to these questions is that it is the right of a human or humans, specifically to their natural heritage and/or to a healthy environment that is protected by these laws and legal procedures. The preambles of EU environmental laws such as the Habitats Directive and Water Framework Directive refer to habitats, species, and water as 'heritage', suggesting their value for humans. However, these interests for humans are unlikely to constitute rights. ${ }^{127}$ Another possible answer is that when the law clearly primarily protects nature, the protected natural entities themselves implicitly hold the substantive rights. On this view, the procedural rights held by the NGO under article 47 would include the right to enforce the substantive EU rights of nature. While this proposition might seem like a stretch, it is ultimately the practical consequence of granting wide standing to environmental NGOs in the fields covered by, for instance, the EU Habitats Directive, thereby granting them the opportunity to act as a guardian ad litem for endangered species and habitats.

This view seems particularly justified when the intrinsic value of the protected nature is legally recognized: instruments such as the Convention on Biological Diversity, which forms part of the EU legal order and influences its biodiversity protection measures, recognizes the intrinsic value of biodiversity and its components. (Interestingly, while the EU 2020 biodiversity strategy recognized the intrinsic value of biodiversity, ${ }^{128}$ the new 2030 biodiversity strategy removed this language, instead recognizing the 'intrinsic connection between human health, animal health and healthy resilient nature' ${ }^{129}$ ) As discussed in section 2, being the intended beneficiary of a law or having ultimate value may support claims to be a rights holder. Arguments by NGOs that they represent the rights of nature might therefore be most successful when the entity whose rights are violated is a species or ecosystem whose intrinsic value is recognized as part of the EU legal order. Interpreting NGOs' procedural environmental rights to enforce the Habitats Directive as a right to represent the substantive rights of natural entities also provides a justification for limiting NGO standing to cases where the NGO is acting in the best interests of natural entities, rather than using environmental litigation as a pretext for the promotion of other interests. ${ }^{130}$

127. As Advocate General Kokott argued regarding the habitats protection provisions of the Habitats Directive in the 2004 Waddenzee case (Case C-127/02, ECLI:EU:C:2004:60), 'there is no evidence to suggest that rights of an individual are established. The objective of protection laid down by Article 6(2) and (3) of the habitats directive is to conserve habitats and species within areas which form part of Natura 2000. Unlike in the case of rules on the quality of the atmosphere or water, [citation omited] the protection of common natural heritage is of particular interest [citation omited] but not a right established for the benefit of individuals. The close interests of individuals can be promoted only indirectly, as a reflex so to speak'.

128. Our life insurance, our natural capital: An EU Biodiversity Strategy to 2020 (COM(2011) 244).

129. EU Biodiversity Strategy for 2030: Bringing Nature Back into Our Lives (COM(2020) $380)$.

130. For example, a US study showed that a majority of lawsuits brought under the California Environmental Quality Act were brought for non-environmental protection purposes such as to promote the 'economic agendas of competitors' to construction projects, or limiting projects that would 'diversify communities by serving members of other races and economic classes', amongst others. Many of these suits were brought by 'newly minted, unincorporated groups with environmental sounding names'. Jennifer Hernandez, 'California Environmental Quality Act Lawsuits and California's Housing Crisis' (2018) 24 Hastings Envt'1 L J 21, 22, 24. The distinction between a genuine environmental protection lawsuit and a pretextual one is of course debatable. 
The Charter's status as a living document is highlighted in Centraal Israëlitisch Consistorie van België and Others. ${ }^{131}$ In that case, the CJEU, in Grand Chamber, stated that the Charter 'must be interpreted in the light of present-day conditions and of the ideas prevailing in democratic States today' in finding that concern for animal welfare was an adequate reason to make limited infringements on religious liberty in relation to the requirement to stun animals prior to slaughter. In that case, the Court used the increasing social concern for animals as justification for limiting a right protected by the Charter. Similarly, if 'changes in values and ideas' favour environmental protection and environmental rights, one might expect the Court to weigh these rights more heavily against other rights and interests. This decision supports the argument that even in the current anthropocentric legal order, meaningful steps can be taken towards the increased legal consideration of the non-human.

\section{LITIGATING NATURE'S RIGHTS IN THE EU}

In a recent chapter in which he examined the possibilities for the recognition of rights for nature in the EU, one of us has argued that currently the strongest opportunities for developing rights of nature are at the Member State level, either through legislation or litigation. ${ }^{132} \mathrm{EU}$ law is an important source of the rights interpretively generated and developed at the Member State level. Additionally, Member State courts are 'first instance' EU courts, and how rights develop in the Member States impacts norms throughout the EU. ${ }^{133}$

Individuals and NGOs are also important actors in a legal system, as courts can only decide matters that have been brought before them. ${ }^{134}$ The interpretation and expansion of rights is often driven by public interest litigation, and given that the EU Commission is keen on facilitating the enforcement of EU environmental laws through court actions by, amongst others, environmental NGOs appearing before national courts, ${ }^{135}$ the current direction of such developments is likely here to stay. Accordingly, environmental public interest litigation based on EU law and developed in Member State courts will continue to exert influence on the jurisprudence of the EU. Persuading Member State courts to use rights language can help to drive the discussion and development of who has rights and of what rights they have under EU law.

Krämer, as we noted in the introduction, is sceptical concerning the possibility of judicial recognition of rights of nature in the EU, arguing that the potential for Member State courts to recognize legal personhood for natural entities is limited to Ireland, the EU's only common law country. ${ }^{136}$ We disagree with Krämer's scepticism for three reasons. First, it is worth noting that while most Member States follow the civil law tradition, the EU courts themselves share similarities with common law

131. Case C-336/19, ECLI:EU:C:2020:1031, para 77.

132. Schoukens (n 24).

133. Opinion 1/09, Creation of a Unified Patent Litigation System (2011) EU:C:2011:123.

134. Yaffa Epstein and Sari Kantinkoski, 'Non-Governmental Enforcement of EU Environmental Law: A Stakeholder Action for Wolf Protection in Finland' (2020) 8 Frontiers in Ecology and Evolution <https://doi.org/10.3389/fevo.2020.00101> accessed 27 April 2021.

135. European Commission (2017) Commission Notice on Access to Justice in Environmental Cases C (2017) 2616 final.

136. Krämer (n 25) 64. 
courts when it comes to judicial lawmaking and developing rights. ${ }^{137}$ Second, it is true in common law as well as civil law systems that the claim of the judiciary tends to be that it does not create new rights, but rather interprets and applies rights that already exist. ${ }^{138}$ Perhaps for this reason, those arguing for nature's rights often frame their claims as seeking recognition of rights that already exist, ${ }^{139}$ or that such rights necessarily follow from the existence of other, established rights. While finding or developing rights or disagreeing with legislatures on how rights should be interpreted has a stronger tradition in common law countries, courts in countries with civil law tradition can also interpret existing rights in unexpected ways. Such interpretive extension was seen, for example, when the Columbian constitutional court held that it was necessary to declare the Atrato River to be a rights-bearing entity in order to effectuate existing constitutional duties to protect the environment, as well as to respect human collective rights to the environment. ${ }^{140}$ The potential for courts to recognize rights for nature within the European Union, we argue, lies in the fact that these rights already implicitly exist in the EU legal order.

Third, rights recognitions for nature do not necessitate recognizing legal personhood for nature. For example, the Ecuadorian constitution establishes substantive rights for Pachamama without declaring her to be a legal person or according her procedural legal rights. ${ }^{141}$ Instead, other legal entities have both the right and duty to protect her rights. ${ }^{142}$ This is similar to the situation we have argued currently exists in the EU, in which protected nature has substantive rights and NGOs have procedural environmental rights to act on nature's behalf. However, while the award of legal personhood and/or of procedural rights to nature is not necessary to bring rights-based claims on behalf of nature, when an entity has rights (and duties, potentially) as intrinsically valuable as nature has, a court may indeed conclude, depending on the jurisdiction, that the entity in question is a legal person. Considering natural entities or even individual specimens of a strictly protected species to be legal persons might not, as is the case with rights, make much immediate difference in how the law is enforced, but it likewise changes the discourse on how humans (and human laws and legal systems) relate to nature, and could eventually encourage more regard for the environment.

It is clear, however, that seeking to vindicate nature's rights through litigation is not necessarily a guarantee of more regard for the environment. While rights of nature advocates have won several important victories such as those in Colombia and

137. Koen Lenaerts and Kathleen Gutman, "Federal Common Law" in the European Union: A Comparative Perspective from the United States' (2006) 54 American Journal of Comparative Law 1, 4, 12.

138. Stephen E Sachs, 'Finding Law' (2019) 107 California Law Review 527, 532 (decribing the 'old vision' of common law judges finding rather than making law, and arguing for its truth).

139. For example, Mary Graham and Michelle Maloney, 'Caring for Country and Rights of Nature in Australia: A Conversation between Earth Jurisprudence and Aboriginal Law and Ethics' in Cameron La Follette and Chris Maser (eds), Sustainability and the Rights of Nature: An Introduction (CRC Press, Boca Raton 2017) 393-4.

140. Center for Social Justice Studies et al. v Presidency of the Republic et al., Judgment T-622/16, Constitutional Court of Colombia (November 10, 2016), section 9.27-9.32 (translated by Dignity Rights Project, Delaware Law School).

141. Ecuador Constitution article 71.

142. Rafi Youatt, 'Personhood and the Rights of Nature: The New Subjects of Contemporary Earth Politics’ (2017) 11 International Political Sociology 39, 49. 
Bangladesh, courts have also declined to recognize rights for nature in other cases and have even struck down legislation that attempted to grant legal rights to nature. For example, the 2019 Lake Erie Bill of Rights, enacted through a citizens' initiative in the American city of Toledo, Ohio, which declared that the lake and its watershed had the 'right to exist, flourish, and naturally evolve' was struck down by a US district court for being unconstitutionally vague. ${ }^{143}$ Several other judicial decisions in the United States have declined standing to natural entities that attempted to enforce municipal rights of nature laws. ${ }^{144}$ Likewise, the Indian Supreme Court stayed a 2017 order by a regional court that recognized the Ganges and its tributary the Yamuna as 'legal persons' in an attempt to protect the highly polluted rivers from further degradation. Moreover, a court is unlikely to accept rights for nature arguments if it considers the proposed right to be incompatible with the legal system in which it is asserted or, if it deems that accepting the right would infringe on the prerogative of the legislative branch of government. To be successful in court, rights of nature advocates must therefore choose legal strategies that are compatible with the legal system they are working within. Basing legal arguments on the Hohfeldian rights that exist in a legal system, and which correspond to existing legal duties, invokes rights on the basis most clearly compatible with the legal system in which such rights are found.

\section{CONCLUSION}

We have argued that protected nature has rights in the EU that correspond to the duties owed to it. Using the example of wolves, we explained that they have Hohfeldian legal rights such as the rights not to be killed, not to be disturbed during mating, and not to have their resting places destroyed. These legal rights are powerful in themselves. Further parallels with fundamental human rights can also be extrapolated, such as a right to life and right to family and property. While the rights of wolves are not explicitly recognized in the EU legal order, these and other rights of protected nature have been given a weight in decisions of the CJEU that is comparable to the weight given to rights, in that protective measures cannot be circumvented for mere utilitarian considerations. Even if the CJEU never explicitly recognizes rights of nature, it seems to give due consideration to the rights nature has.

Rights of nature in the EU are also logically implied by NGOs' procedural environmental rights. The CJEU has held that environmental NGOs have procedural rights to litigate and to participate in procedures in order to enforce EU environmental law, including the Habitats Directive. These procedural rights exist in connection with underlying duties to protect the environment. When environmental laws primarily protect public health, these substantive obligations may reflect Hohfeldian environmental

143. 'If a law is so vague that "persons of common intelligence must necessarily guess at its meaning," it is unconstitutional.' Drewes Farms v City of Toledo, Order Invalidating Lake Erie Bill of Rights, US District Court for the Northern District of Ohio Western Division (2020). 144. For example, the Siletz River Ecosystem was declined standing to intervene to defend a legal challenge to the 'Freedom from Aerially Sprayed Pesticides Ordinance of Lincoln County' in Oregon, USA. Lindsey Schromen-Wawrin and Michelle Amelia Newman, 'Nature's Rights through Lawmaking in the United States' in Cameron La Follette and Chris Maser (eds), Sustainability and the Rights of Nature in Practice (CRC Press, Boca Raton 2019) 327. 
rights for humans. ${ }^{145}$ But when environmental laws, such as the Habitats Directive, primarily protect species and habitats, and only indirectly protect human interests, the underlying rights should be considered to be Hohfeldian rights of natural entities. This argument that some aspects of nature can already be considered to be rights holders can be further supported by the fact that the intrinsic value of biodiversity is recognized in the EU legal order. NGOs' procedural environmental rights can thus be interpreted as being rights to act as guardians ad litem on behalf of natural entities whose substantive rights have been or might be violated.

Many authors have assumed that the recognition of nature's rights would require a complete transformation of the legal system, as well as society. ${ }^{146} \mathrm{We}$ have argued that it requires nothing of the sort because, as we hope we have established, nature already has rights in the current legal system, and these rights can be acknowledged by courts if courts are given the opportunity to do so.

145. Chris Hilson, 'Substantive Environmental Rights in the EU: Doomed to Disappoint?' in Sanja Bogojevic and Rosemary Rayfuse (eds), Environmental Rights in Europe and Beyond (Hart, Oxford 2018) 92.

146. Eg, Cameron La Follette and Chris Maser (eds), Sustainability and the Rights of Nature: An Introduction (CRC Press, Boca Raton 2017); Fritjof Capra and Ugo Mattei, The Ecology of Law: Toward a Legal System in Tune with Nature and Community (Berret-Koehler Publishers, Oakland 2015) 183. 